\title{
EKSPLORASI AUDIT SUMBER DAYA MANUSIA PADA ORGANISASI DI INDONESIA
}

\author{
DITO ADITIA DARMA NASUTION \\ Universitas Pembangunan Pancabudi, Jln. Jend. Gatot Subroto Km. 4,5 Kelurahan Simpang Tanjung, \\ Kecamatan Medan Sunggal, Kota Medan, Provinsi Sumatera Utara 20122, Indonesia \\ ditoaditia@dosen.pancabudi.ac.id
}

\begin{abstract}
Human resources are considered as the most valuable assets for any organisations. However, there are no legislative or financial reporting standards that provide investment quantification methods and any results from human resources. Thus, this study provides an understanding of human resource audit perceptions of organisations in Indonesia. This research successfully highlighted poor awareness and availability of human resource audits in Indonesia. Further hypotheses and tabulations of the data provide in-depth understanding of variations based on sex, sector and nature of the organisations as well as the scope for future research and limitations are explained in this study.
\end{abstract}

Keywords: Human resource audit, human resource, sector, gender, organisations

Abstrak: Sumber daya manusia dianggap sebagai aset yang paling berharga bagi setiap organisasi. Namun tidak ada ketentuan legislatif maupun standar pelaporan keuangan yang menyediakan metode kuantifikasi investasi dan hasil apa pun dari sumber daya manusia. Dengan demikian, penelitian ini memberikan pemahaman persepsi audit sumber daya manusia pada organisasi di Indonesia. Penelitian ini berhasil menyoroti kesadaran yang buruk dan ketersediaan audit sumber daya manusia di Indonesia. Hipotesis dan tabulasi lebih lanjut dari data memberikan pemahaman mendalam tentang variasi berdasarkan jenis kelamin, sektor dan sifat organisasi serta ruang lingkup untuk penelitian di masa depan dan keterbatasan juga dijlaskan pada penelitian ini.

Kata kunci: Audit sumber daya manusia, sumber daya manusia, sektor, jenis kelamin, organisasi

\section{PENDAHULUAN}

Organisasi zaman modern mencari pelembagaan aspek-aspek baru dari optimasi kinerja melalui pemanfaatan sumber daya manusia yang efektif. Kekhawatiran meningkat terhadap aspek biaya dan keuntungan dari setiap investasi yang dilakukan suatu organisasi (Maslova et al, 2017). Secara tradisional tidak ada sistem untuk menganalisis investasi yang dilakukan dalam sumber daya manusia, tetapi saat ini audit sumber daya manusia sudah ada. Hal ini bertujuan untuk memperoleh manfaat optimal dari setiap karyawan melalui perbandingan investasi yang dilakukan dengan hasil yang diberikan. Nilai individu karyawan dipertimbangkan melalui audit sumber daya manusia (Ravas, 2015). Ini tidak hanya mengarah pada penetapan tujuan yang layak dan efektif tetapi juga menghasilkan pemberdayaan karyawan. Karyawan merasa istimewa dan gembira, karena audit sumber 
daya manusia merampingkan semua fungsi sumber daya manusia organisasi dan karenanya membantu dalam sinkronisasi aspirasi individu dengan persyaratan organisasi. Sistem pemantauan yang konstruktif ini meningkatkan kinerja dan efisiensi karyawan secara signifikan. Dalam latar belakang ini, audit sumber daya manusia telah dimasukkan sebagai salah satu praktik kerja terkemuka dalam sistem kerja kinerja tinggi dalam literatur modern (Khosravi \& Hadadi 2018). Praktik kerja kinerja tinggi dianggap memiliki dampak positif pada kinerja karyawan. Selain itu, akan menarik untuk membahas status audit sumber daya manusia di Indonesia yang merupakan salah satu negara yang memiliki peranan dalam perekonomian di kawasan asia tenggara.

Sistem akuntansi keuangan yang saat ini digunakan didasarkan pada konvensi dan prinsip keuangan yang umum dipraktikkan. Meskipun konvensi ini memberikan keseragaman dan kesatuan dengan cara dimana akuntansi kuantitatif aset dan kewajiban bisnis dilaporkan tetapi mereka kehilangan bidang akuntansi kualitatif aset yang paling vital dari organisasi. Salah satu bidang paling vital yang tertinggal adalah sumber daya manusia yang dianggap sebagai aset paling berharga bagi setiap organisasi. Keterbatasan ini telah menantang ahli sumber daya manusia dan keuangan untuk waktu yang lama. Konsekuensinya, diskusi, kolaborasi, dan kebutuhan untuk menyinkronkan aset manusia dengan aset keuangan mengarah pada pengembangan bidang penyelidikan baru yang disebut sebagai audit sumber daya manusia. Dengan kata sederhana, audit sumber daya manusia mengidentifikasi dan mengukur data tentang sumber daya manusia organisasi dan mengkomunikasikan informasi tersebut kepada orang yang bersangkutan.

Alasan di balik obsesi yang berkembang untuk audit sumber daya manusia adalah untuk membantu organisasi dalam merencanakan, mengatur, mengarahkan dan mengendalikan sumber daya manusia secara efektif dan efisien serta untuk memastikan pemanfaatan aset manusia secara optimal. Disinilah analisis biaya dan keuntungan yang dilakukan dari seorang karyawan untuk menentukan nilai karyawan tersebut untuk perusahaannya masing-masing. Peneliti diseluruh dunia telah menyatakan dukungan mereka untuk penilaian sumber daya manusia dalam meningkatkan produktivitas dan profitabilitas perusahaan. Shiri (2012) menyimpulkan enam poin mendasar yang mendukung audit sumber daya manusia. Pertama, menyatakan bahwa audit sumber daya manusia membantu dalam optimalisasi pengembalian investasi yang dilakukan atas aset manusia dalam organisasi. Pengeluaran kompensasi dilaporkan sekitar 15 persen dari rata-rata biaya operasional perusahaan (Garg \& Punia, 2015). 15 persen ini jumlahnya tentu signifikan untuk perusahaan mana pun. Setiap organisasi akan senang memaksimalkan laba atas bagian investasi ini. Kedua, Shiri (2012) melaporkan bahwa audit sumber daya manusia adalah alat yang efisien dan efektif terkait manajemen tenaga kerja dalam suatu organisasi. Pentingnya hubungan antara kinerja dan manajemen sumber daya manusia perusahaan telah dilaporkan oleh para peneliti sebelumnya (Mitrík 2019) dan (Garg \& Punzia 2015). Ketiga, penulis menemukan bahwa audit sumber daya manusia membantu merencanakan, mengatur, mengarahkan, dan mengendalikan karyawan secara efisien dan efektif. Modal manajemen manusia ini memainkan peran kunci dalam implementasi yang sukses sebagian besar inisiatif manajemen dan akibatnya mencapai tujuan strategis perusahaan. Dengan cara ini audit sumber daya manusia disarankan untuk berdampak pada keberhasilan rencana dan strategi manajemen. Selanjutnya, audit sumber daya manusia disorot untuk meningkatkan nilainilai tidak berwujud dalam organisasi.

Mekanisme audit mewarisi modal intelektual kerangka kerja manajemen dan 
pengembangan yang membantu memberikan keterampilan dan kompetensi baru kepada karyawan. Peningkatan nilai tidak berwujud ini dapat menyebabkan peningkatan nilai perusahaan (Chaddha \& Navjayot 2017). Menguraikan konsep lebih lanjut, Doina \& Iconia (2015) mempresentasikan model yang menghubungkan modal intelektual dengan ukuran keuangan perusahaan. Shiri (2012) menyatakan lebih lanjut bahwa hasilnya untuk audit sumber daya manusia akan layanan yang lebih baik untuk manajemen sumber daya manusia klien, proyek peningkatan cakupan dan impor, dan kepuasan pelanggan internal yang ditempatkan dengan baik. Di latar belakang ini audit sumber daya manusia tampaknya memenuhi berbagai macam kebutuhan manajemen setiap organisasi. Tapi sumber daya manusia dalam organisasi belum mengadaptasi audit sumber daya manusia dengan semangat yang cukup dan antusiasme tinggi. (Ravas 2015) menyimpulkan sumber daya manusia itu penilaiannya belum diperkenalkan dalam organisasi di Indonesia sebagai sebuah sistem. Baik standar akuntansi maupun undang-undang persyaratan menggabungkan audit sumber daya manusia. Ikatan Akuntan Indonesia juga belum mengeluarkan standar akuntansi untuk pengukuran dan pelaporan biaya dan nilai sumber daya manusia dari suatu organisasi. Karena itu, audit sumber daya manusia telah menjadi praktik yang diimplementasikan dengan tidak spesifik dan cenderung ragu-ragu dalam sektor korporasi di Indonesia. Namun, audit sumber daya manusia telah menjadi pilar utama dalam meminimalisasi biaya di negaranegara maju khususnya negara barat.

$$
\text { Kesadaran mengacu pada }
$$

pemahaman karyawan yang jelas tentang praktek atau fenomena yang audit sumber daya manusia. Keakraban dan pemahaman membantu dalam pelaksanaan yang tepat dari setiap sistem kerja. Hullah (2012) menyatakan bahwa keberhasilan setiap paket tunjangan kompensasi atau pinggiran tergantung pada kesadaran karyawan.Tingkat kesadaran karyawan yang lebih rendah dapat mengakibatkan pemborosan total dari paket kompensasi yang mahal. Kesadaran mengurangi perlawanan dari karyawan dan karenanya pelembagaan sistem kerja baru menjadi lebih mudah. Khongmalai et al. (2010) menyimpulkan bahwa persepsi karyawan dan kesediaan mereka untuk mengadaptasi sistem kerja baru memiliki dampak signifikan terhadap keberhasilan sistem kerja berkinerja tinggi. Apalagi Purwitasari (2013) menemukan bahwa persepsi karyawan membantu mempelajari sebuah organisasi untuk memahami perilaku dan aspirasi karyawan dalam organisasi. Mardiasmo (2013) meeksplorasi persepsi karyawan dengan sangat rinci. penelitian tersebut menemukan hubungan yang signifikan antara persepsi karyawan akan keberhasilan menuju upaya perubahan yang berkelanjutan dan dirasakan rasa kompetensi. Selanjutnya Wanisa (2016) menyimpulkan bahwa retensi karyawan, pendapatan, penjualan dan keuntungan berkorelasi dengan sikap karyawan dan persepsi kondisi kerja. Liana (2017) juga memberikan kesimpulan sejenis. Mereka menjelaskan bahwa persepsi karyawan memiliki praktek manajemen sumber daya manusia terkait dengan hasil organisasi dan produktivitas. Penelitian lain yang tak terhitung jumlahnya juga menunjukkan pentingnya persepsi karyawan. Sekelompok karyawan yang memiliki persepsi positif dan menguntungkan untuk setiap praktek sangat penting untuk optimasi serta lebih relevan dalam kasus sistem kerja kinerja tinggi karena terdiri dari bundel praktek. Perbedaan persepsi karyawan dapat timbul karena karyawan cenderung mengamati situasi atau informasi yang sama melalui kacamata yang berbeda. Meskipun penelitian sebelumnya telah menyoroti persepsi karyawan dan implikasinya untuk praktik manajemen sumber daya manusia berbeda. Menurut Kang et al. (2018) 
orang memiliki mekanisme inbuilt untuk menyaring informasi eksternal. Mekanisme penyaringan ini tergantung pada sejumlah faktor seperti pengalaman, sikap, sistem kepercayaan, aspirasi, kualifikasi, lingkungan, dan lain-lain. Dengan demikian berbeda dari orang ke orang. Sebagai hasil dari informasi eksternal yang sama disaring berbeda. Dengan demikian menimbulkan berbagai tanggapan sikap dan perilaku. Meskipun penelitian sebelumnya telah menyoroti persepsi karyawan dan implikasi mereka untuk praktek manajemen sumber daya manusisia yang berbeda, tetapi sebuah studi elaborative persepsi karyawan pada audit sumber daya manusia belum dilakukan.

Dalam latar belakang, penelitian ini cenderung untuk mempelajari keselarasan persepsi karyawan untuk audit sumber daya manusia dalam organisasi di Indonesia. Penelitian ini berusaha untuk mengeksplorasi persepsi karyawan untuk audit sumber daya manusia dalam cara yang luas.

\section{METODA}

Sangat jelas dari tinjauan pendahuluan bahwa akuntansi sumber daya manusia masih dalam tahap awal di Indonesia. Tetapi peneliti memperkirakan bahwa di tengah persaingan yang ketat dan upaya pemotongan biaya yang tiada henti, Ikatan Akuntan Indonesia pasti akan menyesuaikan audit sumber daya manusia. Khosravi \& Hadadi (2018) menyatakan bahwa kesadaran dan persepsi karyawan untuk praktik dan fenomena apa pun adalah yang paling penting untuk memperoleh manfaat maksimum dari fenomena atau praktik tersebut. Sejauh ini, belum ada penelitian yang dilakukan terhadap persepsi karyawan terhadap audit sumber daya manusia. Dengan demikian, penelitian ini bercita-cita untuk menjembatani kesenjangan ini dalam pekerjaan penelitian teoritis dan praktis di bidang ini. Dengan kata lain, penelitian ini akan mengeksplorasi kesiapan perusahaan
Indonesia untuk pelembagaan audit sumber daya manusia. Dengan demikian tujuan utama dari penelitian ini telah dibingkai untuk mengeksplorasi kesadaran dan persepsi karyawan untuk audit sumber daya manusia. Tujuan insidental dari penelitian ini adalah sebagai berikut:

1. Untuk memeriksa tingkat kesadaran karyawan dalam audit sumber daya manusia.

2. Untuk mempelajari persepsi karyawan mengenai ketersediaan dan efektivitas audit sumber daya manusia khususnya dalam organisasi di Indonesia.

3. Untuk mempelajari jenis kelamin, variasi organisasi dan sektoral dalam persepsi karyawan untuk audit sumber daya manusia.

Dalam rangka untuk mengeksplorasi tujuan insidental ketiga berikut sembilan hipotesis telah dibingkai dan hipotesis ini lakukan dengan penyelidikan statistik.

$\mathrm{H}_{1}$ : Kesadaran karyawan pria dan wanita berbeda secara signifikan. Di sini, uji two-tailed test akan digunakan.

$\mathrm{H}_{2}$ : persepsi untuk ketersediaan audit sumber daya manusia bervariasi secara signifikan untuk karyawan pria dan wanita.

$\mathrm{H}_{3}$ : ada perbedaan yang signifikan dalam persepsi jenis kelamin untuk efektivitas audit sumber daya manusia.

$\mathrm{H}_{4}$ : kesadaran karyawan sektor publik dan swasta berbeda secara signifikan. Di sini, uji two-tailed test akan digunakan.

$\mathrm{H}_{5}$ : persepsi untuk ketersediaan audit sumber daya manusia bervariasi secara signifikan di antara karyawan sektor publik dan swasta.

$\mathrm{H}_{6}$ : ada perbedaan yang signifikan dalam persepsi karyawan dari dua sektor mengenai efektivitas audit sumber daya manusia. 
$\mathrm{H}_{7}$ : kesadaran akan manufaktur karyawan dan organisasi layanan berbeda secara signifikan. Di sini, uji two-tailed test akan digunakan.

$\mathrm{H}_{8}$ : persepsi untuk ketersediaan audit sumber daya manusia bervariasi secara signifikan di antara karyawan organisasi manufaktur dan layanan.

$\mathrm{H}_{9}$ : ada perbedaan yang signifikan dalam persepsi karyawan dari dua jenis organisasi mengenai efektivitas audit sumber daya manusia.

Penelitian ini didasarkan pada desain penelitian deskriptif-eksploratif menggunakan data primer. Untuk pengumpulan data, kuesioner terstruktur telah disusun yang mencari respons karyawan mengenai kesadaran, ketersediaan, dan efektivitas audit sumber daya manusia mereka. Stratified random sampling telah digunakan untuk mengumpulkan data dari industri di Indonesia. Industri-industri tersebut terutama meliputi perbankan, asuransi, tekstil, BPO, gula, sepatu, konsultasi, minuman dingin, beras dan lain-lain. Ukuran sampel adalah 380 . Kuesioner yang digunakan telah dirancang pada skala lima poin mulai dari 'tidak sadar' (satu) hingga 'sangat sadar' (lima), 'tidak efektif' (satu) hingga 'sangat efektif' (lima) dan 'tidak tersedia' (satu) hingga 'sangat tersedia'(lima). Karyawan diambil dari tingkat atas dan menengah dengan tetap mempertimbangkan bahwa mereka lebih mungkin menghadapi audit sumber daya manusia. Untuk tujuan analisis, telah diawasi secara ketat bahwa sejumlah perusahaan manufaktur, jasa, swasta, publik, Indonesia dan asing didekati. Lebih lanjut saat memberikan kuesioner kepada karyawan, telah dipastikan bahwa data berasal dari semua kategori seperti pria, wanita, sangat berpengalaman untuk yang kurang berpengalaman, personel berusia untuk rekrut baru dan lain-lain. Keandalan data telah diperiksa menggunakan Cronbach's alpha yang dihitung melalui SPSS. Data telah ditabulasi silang untuk memberikan wawasan mendalam ke dalam berbagai aspek dinamika variabel. Desain faktorial telah digunakan untuk membahas efek interaksi lebih dari dua variabel dan pentingnya interaksi ini telah diputuskan dengan bantuan ANOVA.

\section{HASIL}

Banyak penelitian yang telah membuktikan bahwa kesadaran dari setiap praktek atau fenomen sangat penting karena mengarah pada pelaksanaan yang tepat dan fasilitasi. Ketika karyawan menyadari praktik ini mereka akan pergi ke praktek kerja inovatif yang pada akhirnya akan mempengaruhi kinerja individu dan organisasi dalam cara afirmatif. Persepsi lebih lanjut memainkan peran penting bagi individu sebagai praktek yang sama dapat dirasakan berbeda dan ini dapat menyebabkan kontras hasil dan fakta yang sama juga berlaku dalam kasus audit sumber daya manusia. Persepsi karyawan mengenai efektivitas praktek yang mendefinisikan utilitas dan nilai untuk organisasi, seperti dalam kasus jika ada praktek tidak dianggap sebagai efektif oleh karyawan maka karyawan tidak akan berpartisipasi seluruh hati dan karenanya sangat esensi dari praktek akan dikalahkan. Persepsi positif untuk praktek tidak hanya menyiratkan pelaksanaan praktek yang efektif tetapi juga memastikan partisipasi yang efektif dari karyawan juga dan partisipasi ini mengarah pada inovasi dan efektivitas biaya. Dalam hal ini berbagai aspek audit sumber daya manusia telah diambil ke dalam studi dan telah dibahas sebagai berikut: 
Tabel 1 Deskripsi kesadaran, ketersediaan dan tingkat efektivitas audit sumber daya (mean)

\begin{tabular}{llccc}
\hline \multicolumn{1}{c}{ Variabel } & Kategori & $\begin{array}{c}\text { Tingkat } \\
\text { kesadaran }\end{array}$ & $\begin{array}{c}\text { Tingkat } \\
\text { ketersediaan }\end{array}$ & $\begin{array}{c}\text { Tingkat } \\
\text { efektivitas }\end{array}$ \\
\hline Jenis Kelamin & Pria & 2.69 & 2.07 & 3.57 \\
\multirow{3}{*}{ Sektor } & Wanita & 2.31 & 1.79 & 3.31 \\
& Publik & 2.03 & 1.44 & 2.99 \\
Organisasi & Tertutup (Private) & 2.97 & 2.42 & 3.89 \\
& Manufaktur & 2.28 & 1.86 & 3.29 \\
Keseluruhan (rata-rata) & Jasa & 2.72 & 2.00 & 3.59 \\
\hline
\end{tabular}

Tabel 1 memberikan gambaran terperinci tentang persepsi karyawan untuk audit sumber daya manusia. Secara keseluruhan tingkat kesadaran karyawan adalah 2,50 dan pada kategori cukup sadar dari skala 5 poin. Persepsi para karyawan mengenai tingkat ketersediaan dengan nilai mean 1,93 dan pada kategori tersedia sebagian. Persepsi lebih lanjut dari karyawan mengenai tingkat efektivitas memiliki nilai maksimum sebesar 3,44 dan menyatakan bahwa karyawan menganggap audit sumber daya manusia sebagai efektif dalam meningkatkan kinerja karyawan. Pembahasan di atas menyoroti kurangnya ketersediaan dan kesadaran terhadap audit sumber daya manusia yang akut di antara para karyawan organisasi Indonesia. Apalagi karyawan menganggap bahwa praktek Audit memiliki peran yang menguntungkan dan efektif dalam memastikan pemanfaatan sumber daya yang optimal. Data mengungkapkan bahwa meskipun karyawan menganggap audit sumber daya manusia sebagai efektif tetapi kesadaran dan ketersediaan perlu diperkuat.Dengan demikian peneliti menyarankan bahwa organisasi harus mengadakan seminar, lokakarya, ceramah dan pengelolaan manajemen untuk menyebarkan kesadaran mengenai manfaat dan potensi audit sumber daya manusia. Hal ini juga disarankan bahwa perusahaan Indonesia dapat menerapkan audit sumber daya manusia dalam berbagai tahap. Perusahaan dapat memulai proses pelembagaan dari departemen tertentu seperti kualitas atau pemasaran tergantung pada persepsi mereka mengenai efektivitas audit sumber daya manusia.

Lebih lanjut karyawan pria memiliki nilai lebih tinggi daripada kayawan perempuan untuk ketiga parameter (kesadaran, ketersediaan dan efektivitas). Studi ini menyimpulkan bahwa pria relatif lebih siap dan cenderung untuk adopsi audit sumber daya manusia. Namun alasan perbedaan gender tersebut di luar lingkup studi sekarang dan masa depan peneliti dapat menyelidiki pada saat yang sama. penulis menyarankan bahwa jika perbedaan gender ditemukan untuk menjadi signifikan daripada organisasi tidak dapat menggunakan rute yang sama dan mekanisme untuk beradaptasi audit sumber daya manusia untuk kedua jenis kelamin. Teknik persiapan khusus seperti program sensitisasi audit sumber daya manusia bagi karyawan perempuan dapat membantu untuk menjembatani kesenjangan persepsi antara dua pemikiran. Tapi sebelum tiba pada kesimpulan perbedaan gender harus diperiksa untuk signifikansi statistik seperti yang dijelaskan dalam hipotesis.

Lebih lanjut menarik untuk mengetahui bahwa karyawan sektor swasta memiliki persepsi yang lebih tinggi dari ketiga parameter daripada karyawan sektor publik. Kesadaran karyawan (Mean $=2.03$ ) dan persepsi karyawan mengenai ketersediaan (Mean = 1044) tetap terlalu rendah untuk organisasi 
sektor publik. Dengan demikian nilai tabulasi menandakan status yang relatif buruk audit sumber daya manusia dalam organisasi sektor publik.Tabel menyoroti titik menarik lainnya yaitu karyawan organisasi layanan juga dinilai lebih tinggi di semua tiga parameter daripada karyawan organisasi manufaktur. Signifikansi lebih lanjut dari perbedaan ini dibahas melalui pengujian hipotesis.
Saat ini pertumbuhan eksponensial partisipasi perempuan di tempat kerja meningkat. Peningkatan fenomenal keragaman gender tenaga kerja ini menarik bagi peneliti dan praktisi. Sejumlah besar studi dikenakan untuk mendiskusikan pelaksanaan keragaman gender pada kinerja organisasi. Di sini juga, di bawah hipotesis cenderung untuk mendiskusikan perbedaan persepsi di antara gender.

Tabel 2 Pengujian hipotesis (jenis kelamin laki-laki dan perempuan)

\begin{tabular}{cccc}
\hline Hipotesis & Nilai Z & Nilai kritis & Hasil \\
\hline Hipotesis-1 & 0.96 & 1.96 & Diterima \\
Hipotesis-2 & 1.65 & 1.96 & Diterima \\
Hipotesis-3 & 1.88 & 1.96 & Diterima \\
\hline
\end{tabular}

Tabel 2 menyatakan bahwa hipotesis null diterima dan karenanya perbedaan dalam persepsi laki dan perempuan keluar untuk menjadi tidak signifikan untuk ketiga parameter yang diambil dalam studi. Jadi perbedaan persepsi antara gender dibuang dengan ini. Ini menandakan bahwa tidak ada perlakuan yang terpisah diperlukan bagi karyawan pria dan wanita untuk melembagakan audit sumber daya manusia dalam organisasi. Temuan ini signifikan karena banyak praktik sumber daya manusia kehilangan relevansi dan utilitas karena perbedaan persepsi berdasarkan gender. Khongmalai et al (2010) melaporkan bahwa perseptual perbedaan dapat menyebabkan kecurigaan dan ketidakpercayaan untuk setiap praktek sumber daya manusia baik karyawan laki-laki ataupun perempuan. Perbedaan persepsi juga menciptakan kesenjangan dalam penerimaan dan adaptasi di antara gender dan karenanya seluruh tujuan pelaksanaan praktek sumber daya manusia akan dikalahkan.

Ada perbedaan yang terlihat dalam kinerja organisasi sektor publik dan swasta. Organisasi sektor swasta umumnya dikaitkan dengan omset dan keuntungan selama periode waktu. Namun, setelah 1991 prinsip profesionalisme, manajemen, inovasi dan orientasi pelanggan akan menyerap ke dalam budaya kerja organisasi sektor publik. Ini telah berkurang kesenjangan antara dua sektor. Penelitian perseptual baru-baru ini juga petunjuk terhadap melemahnya perbedaan persepsi di antara dua sektor. Di sini, akan menarik untuk mengeksplorasi kesadaran dan persepsi perbedaan untuk audit sumber daya manusia. Hipotesa nomor 4, 5, dan 6 melihat ke persepsi kesenjangan atau perbedaan antara karyawan dari dua sektor.

Tabel 3 Pengujian hipotesis (sektor publik dan privat)

\begin{tabular}{cccc}
\hline Hipotesis & Nilai Z & Nilai kritis * & Hasil \\
\hline Hipotesis-4 & 3.55 & 1.96 & Ditolak \\
Hipotesis-5 & 4.02 & 1.96 & Ditolak \\
Hipotesis-6 & 1.88 & 1.96 & Ditolak \\
\hline
\end{tabular}


Tabel 3 menggambarkan bahwa ketiga hipotesa null ditolak dan satu hipotesis null diterima. Hal ini menandakan bahwa kesadaran dan persepsi mengenai ketersediaan audit sumber daya manusia berbeda secara signifikan untuk dua sektor. Lebih rendah nilai berarti bagi karyawan sektor publik menyoroti kesiapan yang lebih rendah untuk adopsi praktik audit di sektor publik karyawan. Temuan menunjukkan bahwa karyawan dari kedua sektor merasakan audit sumber daya manusia sebagai sama efektif tetapi ada ketersediaan dan kesadaran terhadap keprihatinan untuk organisasi sektor publik. Data menunjukkan bahwa oeganisasi sektor publik yang diperlukan untuk bekerja pada tingkat kesadaran karyawan mereka sebelum membuat rencana untuk melaksanakan audit sumber daya manusia. Seminar, workshop, kunjungan ke perusahaan swasta, interaksi dengan SDM profesional atau bantuan agen eksternal, dan lain-lain dapat membantu dalam membangun pengetahuan karyawan pemerintah sehingga manfaat maksimum audit sumber daya manusia dapat dirasakan.

Ekonomi Indonesia naik tinggi pada keberhasilan organisasi layanan, sebagai bagian utama dari PDB disumbangkan oleh organisasi tersebut. Tapi negara perlu untuk mempercepat output industri juga, karena dapat menciptakan ketidakseimbangan dalam perekonomian. Berikut hipotesis mengeksplorasi variasi perseptual di antara dua jenis organisasi dan dengan demikian mendiskusikan perbedaan dalam kesiapan karyawan untuk audit sumber daya manusia.

Tabel 4 Pengujian hipotesis (manufaktur dan organisasi layanan)

\begin{tabular}{cccc}
\hline Hipotesis & Nilai Z & Nilai kritis * & Hasil \\
\hline Hipotesis-1 & 7.15 & 1.96 & Diterima \\
Hipotesis-2 & 8.41 & 1.96 & Diterima \\
Hipotesis-3 & 0.98 & 1.96 & Diterima \\
\hline
\end{tabular}

Di sini dua hipotesa null pertama ditolak dan yang ketiga diterima. Ini menyiratkan bahwa kesadaran dan persepsi mengenai efektivitas audit sumber daya manusia berbeda secara signifikan di antara karyawan dari organisasi manufaktur dan layanan. Lagi berarti nilai lebih tinggi untuk organisasi layanan, itu menyoroti semakin perlu melengkapi organisasi manufaktur dengan praktik tersebut.

Tabel 5 Tabulasi silang (tngkat kewaspadaan)

\begin{tabular}{lcccccc}
\hline \multirow{2}{*}{ Variabel } & \multicolumn{2}{c}{ Gender } & \multicolumn{2}{c}{ Sektor } & \multicolumn{2}{c}{ Organisasi } \\
& Laki-laki & Perempuan & Publik & Privat & Manufaktur & Layanan \\
\hline Laki-laki & 2.69 & - & 2.41 & 2.97 & 2.55 & 2.83 \\
Perempuan & - & 2.31 & 1.65 & 2.97 & 2.01 & 2.61 \\
Publik & 2.41 & 1.65 & 2.03 & - & 1.87 & 2.19 \\
Privat & 2.97 & 2.97 & - & 2.97 & 2.69 & 3.25 \\
Manufaktur & 2.55 & 2.01 & 1.87 & 2.69 & 2.28 & - \\
Layanan & 2.83 & 2.61 & 2.19 & 3.25 & - & 2.72 \\
\hline
\end{tabular}

\begin{abstract}
Di atas hipotesis dibahas variasi dalam tingkat kesadaran gender, sektor dan organisasi. Sekarang data telah lintas tabulasi untuk memberikan wawasan mendalam efek interaksi tiga parameter studi ini. Signifikansi lebih lanjut dari efek interaksi juga dibahas dengan bantuan ANOVA. Dalam urutan ini data kesadaran karyawan telah tertabulasi.
\end{abstract}


Tabel 5 memberikan gambaran yang luas tentang kesadaran untuk mekanisme ganti rugi keluhan di antara ketiga parameter studi. Pria karyawan sektor publik (Mean $=2.41$ ) kurang sadar daripada laki-laki karyawan sektor swasta (Mean $=2,97$ ) dan sama perempuan karyawan sektor swasta lebih sadar daripada perempuan karyawan sektor publik.
Menariknya sama halnya dalam kasus organisasi manufaktur dan layanan, dengan kedua jenis kelamin di sektor jasa memiliki keunggulan atas rekan mereka di sektor manufaktur. Karyawan organisasi layanan pribadi $($ Mean $=3.25)$ memiliki kesadaran maksimum untuk audit sumber daya manusia.

Tabel 6 Signifikansi dalam desain faktorial (tingkat kewaspadaan)

\begin{tabular}{|c|c|c|c|}
\hline No & Variabel Independen 1 & Variabel Independen 2 & Nilai \\
\hline 1 & $\begin{array}{l}\text { Jenis Kelamin: Laki-laki dan } \\
\text { Perempuan }\end{array}$ & Sektor Publik dan Swasta & 0,001 \\
\hline 2 & $\begin{array}{l}\text { Jenis Kelamin: Laki-laki dan } \\
\text { Perempuan }\end{array}$ & Organisasi Manufaktur dan Layanan & 0,442 \\
\hline 3 & Sektor Publik dan Swasta & Organisasi Manufaktur dan Layanan & 0,061 \\
\hline
\end{tabular}

Tabel 6 menyatakan bahwa salah satu desain faktorial yaitu sektor gender memiliki nilai signifikan kurang dari 0,05 yang menyiratkan bahwa efek interaksi gender dan sektor adalah signifikan. Ini berarti gender dan sektor dalam kombinasi akan menghasilkan perbedaan persepsi. Efek interaksi dalam sisa desain faktorial ditemukan tidak signifikan, yang berarti persepsi karyawan pria atau wanita tidak berbeda dalam dua jenis organisasi.

Tabel 7 Tabulasi silang (tingkat ketersediaan)

\begin{tabular}{lcccccc}
\hline \multicolumn{1}{c}{ Variabel } & \multicolumn{2}{c}{ Gender } & \multicolumn{2}{c}{ Sektor } & \multicolumn{2}{c}{ Organisasi } \\
& Laki-laki & Perempuan & Publik & Privat & Manufaktur & Layanan \\
\hline Laki-laki & 2.07 & - & 1.85 & 2.29 & 1.91 & 2.23 \\
Perempuan & - & 1.79 & 1.49 & 2.09 & 1.60 & 1.98 \\
Publik & 1.85 & 1.49 & 1.44 & - & 1.31 & 1.57 \\
Privat & 2.29 & 2.09 & - & 2.42 & 2.40 & 2.43 \\
Manufaktur & 1.91 & 1.60 & 1.31 & 2.40 & 1.86 & - \\
Layanan & 2.23 & 1.98 & 1.57 & 2.43 & - & 2.00 \\
\hline
\end{tabular}

Tabel 7 memberikan penjelasan terperinci tentang persepsi karyawan mengenai tersedianya audit sumber daya manusia. Di sini karyawan pria dari sektor publik (Mean $=1,85$ ) merasakan audir sumber daya manusia kurang tersedia daripada pria karyawan sektor swasta (Mean $=2,29)$. Data lebih lanjut dari tabel $\mathrm{di}$ atas sesuai dengan data tabel 5 dengan peringkat sektor swasta yang lebih tinggi dari organisasi sektor publik untuk kedua jenis kelamin. Sekali lagi organisasi layanan menunjukkan ketersediaan maksimum sistem audit. 
Tabel 8 Signifikansi dalam desain faktorial (tingkat ketersediaan)

\begin{tabular}{|c|c|c|c|}
\hline No & Variabel Independen 1 & Variabel Independen 2 & Nilai \\
\hline 1 & $\begin{array}{l}\text { Jenis Kelamin: Laki-laki dan } \\
\text { Perempuan }\end{array}$ & Sektor Publik dan Swasta & 0,049 \\
\hline 2 & $\begin{array}{l}\text { Jenis Kelamin: Laki-laki dan } \\
\text { Perempuan }\end{array}$ & Organisasi Manufaktur dan Layanan & 0,001 \\
\hline 3 & Sektor Publik dan Swasta & Organisasi Manufaktur dan Layanan & 0,039 \\
\hline
\end{tabular}

Tabel 8 menggambarkan bahwa ketiga desain faktorial yang signifikan yang berarti efek interaksi antara ketiga parameter studi yang signifikan dan memiliki bantalan pada persepsi karyawan. Dalam kata sederhana karyawan di sektor yang berbeda atau di seluruh organisasi yang berbeda akan memiliki persepsi yang berbeda mengenai ketersediaan audit sumber daya manusia. Sama juga berlaku untuk karyawan perempuan.

\section{Tabel 9 Tabulasi silang (tingkat efektivitas)}

\begin{tabular}{lcccccc}
\hline \multirow{2}{*}{ Variabel } & \multicolumn{2}{c}{ Gender } & \multicolumn{2}{c}{ Sektor } & \multicolumn{2}{c}{ Organisasi } \\
& Laki-laki & Perempuan & Publik & Privat & Manufaktur & Layanan \\
\hline Laki-laki & 3.57 & - & 3.21 & 3.93 & 3.40 & 3.74 \\
Perempuan & - & 3.31 & 2.77 & 3.85 & 3.18 & 3.44 \\
Publik & 3.21 & 2.77 & 2.99 & - & 2.81 & 3.17 \\
Privat & 3.93 & 3.85 & - & 3.89 & 3.72 & 4.06 \\
Manufaktur & 3.40 & 3.18 & 2.81 & 3.72 & 3.29 & - \\
Layanan & 3.74 & 3.44 & 3.17 & 4.06 & - & 3.59 \\
\hline
\end{tabular}

Persepsi karyawan mengenai efektivitas sistem audit sumber daya manusia tidak sangat bervariasi di antara dua jenis kelamin dalam organisasi manufaktur dan jasa. Tapi persepsi karyawan tampaknya berada di kutub yang berlawanan untuk karyawan pria dan wanita dari sektor publik dan swasta. Pria karyawan sektor publik memiliki nilai berarti 3,21 sementara nilai yang sesuai untuk perempuan karyawan 2,77. Karyawan organisasi layanan merasakan audit sumber daya manusia sebagai sangat efektif dengan nilai rata 4,06. Signifikansi persepsi perbedaan dibahas melalui Tabel 10.

Tabel 10 Signifikansi dalam desain faktorial (tingkat efektivitas)

\begin{tabular}{|c|c|c|c|}
\hline No & Variabel Independen 1 & Variabel Independen 2 & Nilai \\
\hline 1 & $\begin{array}{l}\text { Jenis Kelamin: Laki-laki dan } \\
\text { Perempuan }\end{array}$ & Sektor Publik dan Swasta & 0,040 \\
\hline 2 & $\begin{array}{l}\text { Jenis Kelamin: Laki-laki dan } \\
\text { Perempuan }\end{array}$ & Organisasi Manufaktur dan Layanan & 0,115 \\
\hline 3 & Sektor Publik dan Swasta & Organisasi Manufaktur dan Layanan & 0,055 \\
\hline
\end{tabular}


Di sini hanya satu desain faktorial ditemukan untuk menjadi signifikan. Efek interaksi antara gender dan sektor adalah signifikan. Sementara efek interaksi antara dua desain yang tersisa ditemukan tidak signifikan.

\section{PENUTUP}

Persepsi adalah hal yang unik dan pribadi untuk setiap individu. Sangat sulit untuk menemukan dua individu berbeda yang memiliki pendapat yang benar-benar sama pada pokok bahasan tertentu. Penelitian ini mengeksplorasi status dan variasi dalam persepsi karyawan untuk audit sumber daya manusia. audit sumber daya manusia telah memperoleh perbedaan antara praktek kinerja tinggi dengan keunikan dari kuantifikasi sumber daya manusia. Penelitian ini menyoroti bahwa status audit sumber daya manusia buruk dalam organisasi di Indonesia, dengan tingkat kesadaran dan ketersediaan yang buruk. Perhatian yang lebih besar adalah untuk manufaktur dan organisasi sektor publik. Penelitian ini dapat bertindak sebagai cermin untuk apa yang disebut organisasi Indonesia modern karena mereka tidak mengadaptasi cara yang lebih baru dari kuantifikasi modal manusia. Dengan meningkatnya keprihatinan pada laba atas investasi yang lebih tinggi, audit sumber daya manusia ditempatkan dengan baik untuk memperoleh tempat penting dalam setiap organisasi modern. Dengan demikian organisasi disarankan untuk melakukan studi persepsi terlebih dahulu sebelum melaksanaan audit sumber daya manusia. Jika kasus praktisi SDM melaporkan setiap kesalahan persepsi atau kekurangan terhadap audit sumber daya manusia, para ahli harus berkonsultasi untuk rektifikasi persepsi karyawan terhadap audit sumber daya manusia. Studi ini memberikan wawasan penting bagi para peneliti masa depan juga. Penelitian selanjutnya dapat mengeksplorasi berbagai alasan untuk kekurangan akut audit sumber daya manusia dalam organisasi Indonesia. Apalagi perseptual perbedaan di dua sektor juga bisa menjadi masalah investigasi. Analisis korelasi antara tingkat kesadaran dan persepsi mengenai ketersediaan dan efektivitas juga dapat dieksplorasi dengan semangat yang lebih besar. Temuan dari studi ini dibatasi oleh ukuran sampel yang hanya berjumlah 380 . Ukuran sampel yang lebih besar akan membantu dalam deskripsi perseptual yang lebih akurat dari audit sumber daya manusia. Kurangnya studi persepsi dan kelangkaan eksplorasi audit sumber daya manusia dalam pengaturan Indonesia tidak memungkinkan peneliti untuk memiliki perbandingan hasil dengan studi sebelumnya.

\section{REFERENCES:}

Chaddha, S., \& Navjayot. 2017. Manpower Study: Analysis of a State Technical University. Journal of Organisation \& Human Behaviour, 6(3), 30-36. Retrieved from http://escweb.lib.cbs.dk/login?url=http://search.ebscohost.com/login.aspx?direct=true\&db=bth\&AN=126454 $355 \&$ site $=$ ehost-live

Doina, L. E., \& Iconia, T. A. 2015. Human Resources Audit- Primary Function of The Resources Management. Anale. Seria Stiinte Economice, 21(1), 188-190.

Garg, N., \& Punia, B. K. 2015. Exploring Human Resource Audit (HRA) in Indian Organisations. FIIB Business Review, 4(3), 56-63. https://doi.org/10.1177/2455265820150310

Hullah, A. R. 2012. Pengaruh Sumber Daya Manusia dan Pemanfaatan Teknologi Informasi Terhadap Keterandalan Pelaporan Keuangan pada Pemerintah Provinsi Sulawesi Utara. Jurnal Riset Akuntansi Dan Auditing, 3(2). 
Kang, S. M., Hwang, I. T., \& Hur, K. S. 2018. Effect Of Changes In The Korean Accounting Environment On The Productivity Of Accounting Firms. Journal of Applied Business Research, 34(1), 55-68.

Khongmalai, O., Tang, J. C. S., \& Siengthai, S. 2010. Empirical evidence of corporate governance in Thai state-owned enterprises. Corporate Governance, 10(5), 617-634. https://doi.org/10.1108/14720701011085580

Khosravi, H., \& Hadadi, E. 2018. The Effect of Enabling Organizational Factors on Human Resources Productivity in the Supreme Audit Court. Journal of Economic \& Management Perspectives, 12(1), 290-298.

Liana, G. 2017. Marketing Audit and Its Importance in Achievement of Marketing Objectives of a Company. Journal of Advanced Research in Management, 8(15), 38-43. https://doi.org/10.14505/jarm.v8.1(15).04

Mardiasmo, M. 2013. Assessing Accountability Of Performance Measurement System And Local Government Budgetary Management. Gadjah Mada International Journal of Business, 4(3), 373395. https://doi.org/10.22146/gamaijb.5388

Maslova, E. V., Kulchitskya, E. V., Melyakova, E. V., Kizyan, N. G., \& Penzina, O. S. 2017. Model of an organization's internal environment development on the basis of human resource audit. Journal of Advanced Research in Law and Economics, 8(1), 118-127. https://doi.org/10.14505/jarle.v8.1(23).14

Mitrík, K. 2019. Achieving Audit Quality: A Path Lined With Obstacles, As Well As Treasures. International Journal of Government Auditing, 46(3), 4-6.

Purwitasari, A. 2013. Pengaruh Pengendalian Internal dan Komitmen Organisasi dalam Pencegahan Fraud Pengadaan Barang (Survey pada 5 Rumah Sakit di Bandung). Universitas Widyatama Bandung.

Ravas, B. 2015. Simulation of Internal Audit Within the Department of Human Resources in an Economic Entity From the Public Sector. Annals of the University of Petrosani : Economics, 15(2), 143-150.

Shiri, S. 2012. Audit as a Tool for Improving HR Functions. Review of HRM, 1(April), 34-43.

Wanisa, Z. 2016. Kinerja Pegawai Dinas Pengelolaan Bangunan Dan Tanah dalam Pelaksanaan Inventarisasi Aset Tanah di Kota Surabaya. Jurnal Kebijakan Dan Manajemen Publik, 4(2), 34-45. 